\title{
GREEN GROWTH, GREEN ECONOMY AND SUSTAINABLE DEVELOPMENT: TERMINOLOGICAL AND RELATIONAL DISCOURSE
}

\section{Armand Kasztelan*}

\begin{abstract}
The purpose of the survey and to some extent polemical article is to present the issue of green growth, a new operating strategy, which the OECD is currently working on. Green growth is seen as a practical tool for achieving the timeless objective, which is sustainable development. In the paper, a particular attention is put on the following question: what kind of relationship occurs between green growth, green economy and sustainable development. The author analyses the purpose of simultaneous functioning of the three "green" ideas. The added value of this paper is a presentation of the author's model of GG-GE-SD relations and a new approach to defining the phenomenon of green growth. It is concluded that co-existence of the trio green economy green growth - sustainable development is reasonable due to the complementary and synergistic nature of correlations between these concepts.
\end{abstract}

Keywords: green growth, green economy, sustainable development, OECD, UNEP JEL Classification: O44, Q56, Q58

\section{Introduction}

Globally, the last economic and financial crisis has caused a temporary reduction of human impact on the environment. It is expected, however, that a return to the path of dynamic growth will result in intensification of environmental burdens exceeding the levels recorded before the recession. To address these concerns, a new strategy for action was identified at the meeting of the OECD Ministerial Council - the so-called Green Growth Strategy, which in Polish translations of the OECD documents is also referred to as the Strategy of Ecological Development or Ecological Economic Growth (OECD, 2014, 2011b, 2011c, 2011d).

According to the definition formulated by the OECD (OECD, 2011a), green growth means taking measures conducive to growth and economic development, while ensuring that natural assets continue to provide the resources and environmental services which contribute to the country's prosperity. Green growth focuses on accelerating investments and innovations that will underpin sustainable development and provide new economic opportunities. Reilly (2012) states that the push for green economic growth expresses the intention to direct the economy towards technologies and consumption patterns that create jobs and economic growth as well as reduce the impact on the environment.

Armand Kasztelan, University of Life Sciences in Lublin, Faculty of Agrobioengineering, Department of Economics and Agribusiness, Akademicka 13, 20-950 Lublin, Poland (armand. kasztelan@up.lublin.pl). 
It focuses on cost-effective ways of reducing pressure on the environment allowing for transition to new models of development, which in turn will avoid crossing critical local, regional, and global environmental thresholds. According to the assumptions, green growth strategies developed at the national level should encourage environmentally friendly behaviour of businesses and consumers, improve the optimal reallocation of labour, capital, and technology towards greener operations, and provide motivation for the development of eco-innovations (OECD, 2011b; Kijek, Kasztelan, 2013).

This article is a discourse ordering issues and specifying terms connected with the so-called green growth. The basic goal of the article is to answer the question of what kind of relationship occurs between the concepts of green growth, green economy and sustainable development. Are these three ideas mutually exclusive or, on the contrary, are they logically interconnected? The starting point for considerations will be a discussion of the origin and essence of the analysed concepts. Then, relationships between green growth and the idea of green economy will be discussed. An important element of the discussion will also be the reference of the concept of green growth to the still valid paradigm of sustainable development. In the final part of the study the author will propose a self-designed model of GG-GE-SD relations. The author argues that the restructuring of economy aiming at the so-called "green" solutions (green economy), based on the assumptions of the strategy of green growth, is the basic condition for entering the path of sustainable development.

For the purposes of implementing the main research objective the article makes use of the literature method, comparative method and deductive reasoning. The article concludes with a summary identifying the areas for further research.

\section{What does green growth really mean?}

Currently the world has to face two key challenges, i.e. fast growing global population and the related increasing pressure on the environment, which should be quickly prevented primarily through correct internalisation of external effects.

Due to the scale of existing risks, the key challenges concern issues connected with climate changes. They necessitate undertaking the required preventive measures but the lack of an agreed position in international negotiations concerning the division of burdens made respective countries look independently for possible ways to balance their national paths of economic growth with potential problems, such as environmental pollution and exhausting natural resources. The above-mentioned conditions resulted, among other things, in the emergence of the concept of green growth (Satbyul et al., 2014).

In 2009, partly in response to the global financial downturn, South Korea adopted the National Strategy for Green Growth and the 5-Year Plan for Green Growth. Since that time South Korea has been the main ambassador of this concept promoting it throughout the world, mainly through the OECD platform. At the OECD Ministerial Council Meeting in June 2009, 30 members and five candidate countries (in total accounting for about 80\% of the overall global economic potential) adopted a declaration stating that environmental protection and economic growth can be parallel. At the same time, a decision was made to commence works on the green growth strategy to enable comprehensive treatment of economic, environmental, social and technological aspects (UNESCAP, 2012). Currently, the OECD is a leading institution supporting the implementation of green 
growth in respective countries. In addition, many other international organisations (World Bank, Green Growth Leaders), think-tanks as well as representatives of the world of science focussed on green growth, which resulted in a number of definitions (Table 1) (Allen and Clouth, 2012).

Table 1 | Selected Definitions of Green Growth

\begin{tabular}{|c|c|}
\hline Source & Definition \\
\hline $\begin{array}{l}\text { The Address by President } \\
\text { Lee Myung-bak on the } 60 \text { th } \\
\text { anniversary of the founding } \\
\text { of the Republic of Korea, } \\
\text { August 15, 2008 (Republic } \\
\text { of Korea, 2009) }\end{array}$ & $\begin{array}{l}\text { "Green growth refers to sustainable growth that mitigates } \\
\text { greenhouse gas emissions, and prevents environmental degradation. } \\
\text { It is also a new national development paradigm that creates new } \\
\text { growth engines and jobs through green technology and clean } \\
\text { energy." }\end{array}$ \\
\hline $\begin{array}{l}\text { Framework Act on Low } \\
\text { Carbon, Green Growth, } \\
\text { (Republic of Korea, 2010) }\end{array}$ & $\begin{array}{l}\text { "...growth achieved by saving and using energy and resources } \\
\text { efficiently to reduce climate change and damage to the environment, } \\
\text { securing new growth engines through research and development } \\
\text { of green technology, creating new job opportunities, and achieving } \\
\text { harmony between the economy and environment..." }\end{array}$ \\
\hline $\begin{array}{l}\text { Government of Rwanda, } \\
2011 \text { (Republic of Rwanda, } \\
\text { 2011) }\end{array}$ & $\begin{array}{l}\text { "...an emerging concept that recognizes that environmental } \\
\text { protection is a driver of global and national economic development. } \\
\text { It refocuses society on achieving qualitative growth rather than } \\
\text { simply increasing GDP..." }\end{array}$ \\
\hline OECD, 2011 & $\begin{array}{l}\text { "...aims to foster economic growth and development, while ensuring } \\
\text { that natural assets are used sustainably, and continue to provide } \\
\text { the resources and environmental services on which our well-being } \\
\text { relies..." }\end{array}$ \\
\hline World Bank, 2012 & $\begin{array}{l}\text { "...growth that is efficient in its use of natural resources, clean in that } \\
\text { it minimizes pollution and environmental impacts and resilient in that } \\
\text { it accounts for natural hazards..." }\end{array}$ \\
\hline UNESCAP, 2012 & $\begin{array}{l}\text { "...environmentally sustainable economic progress to foster } \\
\text { low-emission, socially inclusive development..." }\end{array}$ \\
\hline $\begin{array}{l}\text { Global Green Growth } \\
\text { Institute (GGGI), } 2012\end{array}$ & $\begin{array}{l}\text { "...new revolutionary development paradigm that sustains economic } \\
\text { growth while at the same time ensuring climatic and environmental } \\
\text { sustainability..." }\end{array}$ \\
\hline
\end{tabular}

Source: own elaboration

In 2011 during the OECD forum a package of documents was presented forming part of the so-called Green Growth Strategy. The strategy is regarded a useful tool for adding dynamics to the economic growth and creating green jobs through the more sustainable use of natural resources, increased energy and material effectiveness and proper valuation of environmental services (OECD, 2012). The Green Growth Strategy should, in the first place, contribute to creating and developing a new framework for national accounts taking into consideration environmental issues and general social welfare. Secondly, it should provide specific tools and recommendations for formulating national policies to help governments most effectively change to sustainable economy 
and achieve sustainable development. Thirdly, it should constitute a significant source of information on ways to support green growth in countries with emerging and developing economies. Fourthly, the Strategy focuses on employment issues, including possibilities to create new jobs both in the short and long run, which is significant from the point of view of the social dimension of sustainable development (OECD, 2009).

According to the OECD, formulating and implementing national green growth strategies is necessary because the impact of social and economic processes on ecosystems causes imbalance, inducing risk to economic growth and development processes. In addition, natural capital, including mineral resources, is often underestimated and thus poorly managed. This, in turn, generates costs for the economy and contributes to the deterioration of overall social welfare (OECD, 2011b). The lack of consistent strategies to handle such problems induces uncertainty, putting investment and innovation on hold, and thus it can decelerate the process of sustainable development.

In other words, the purpose of national strategies and programmes of green growth is to motivate businesses and consumers to undertake more environment-friendly activities, facilitate smooth and equitable reallocation of jobs, capital and technologies and to provide proper incentive and support in the context of developing ecological innovations (OECD, 2012).

\section{Green growth versus green economy}

Green growth is strictly connected with the idea of green economy oriented at increased overall social welfare and social justice, at the same time considerably reducing environmental risks and ecological deficiencies (UNEP, 2011).

Although the concept of green growth has recently become a notable issue on the international arena, in scientific communities it has been subject to discussions and analyses continuing for decades, in particular in the area of the so-called environmental and ecological economics.

For the first time the term green economy was used in the report entitled Blueprint for a Green Economy of 1989, prepared for the government of the United Kingdom by a group of leading environmental economists (Barbier, 2009). However, apart from the title it contained no further references to green economy, thus it seems that the term was used by the authors as a kind of reflection.

In 2008 the term was kind of "refreshed" in the context of measures undertaken in response to the world crisis. In October 2008 UNEP initiated the so-called Green Economy Initiative in order to ensure analyses and political support for investments in "green" sectors of economy but also to make conventional, material-consuming and pollution-generating sectors "green". In April 2009 the Global Green New Deal (GGND) report was issued. It contained a proposal of measures for economic reconstruction and reinforcement of stability of the world economy. In turn, in February 2010, ministers and heads of the delegation of the Global Environment Forum in Nusa Dua recognized the leading role of UNEP in further defining and promoting the concept of green economy (Allen and Clouth, 2012).

In 2011, the UNEP prepared the Green Economy Report which contained a working definition of green economy, quoted many times in numerous other publications. The UNEP has defined the green economy as "one that results in improved human well- 
being and social equity, while significantly reducing environmental risks and ecological scarcities. It is low carbon, resource efficient, and socially inclusive" (UNEP, 2011). To date this has been the most comprehensive - and agreed at the international forum definition of green economy, whereas in literature at least five different ways to define this phenomenon can be identified (Table 2).

Table 2 | Selected Definitions of Green Economy

\begin{tabular}{|c|c|}
\hline Source & Definition \\
\hline $\begin{array}{l}\text { UNEP's working } \\
\text { definition (UNEP, } \\
\text { 2010b) }\end{array}$ & $\begin{array}{l}\text { "...a system of economic activities related to the production, } \\
\text { distribution and consumption of goods and services that result in improved } \\
\text { human well-being over the long term, while not exposing future } \\
\text { generations to significant environmental risks or ecological scarcities..." }\end{array}$ \\
\hline $\begin{array}{l}\text { Green Economy } \\
\text { Coalition, } 2010\end{array}$ & $\begin{array}{l}\text { "...a resilient economy that provides a better quality of life for all } \\
\text { within the ecological limits of the planet..." }\end{array}$ \\
\hline $\begin{array}{l}\text { The UNEP-led Green } \\
\text { Economy Initiative } \\
\text { (UNEP, 2011) }\end{array}$ & $\begin{array}{l}\text { economy "that results in improved human well-being and social equity, } \\
\text { while significantly reducing environmental risks and ecological scarcities. } \\
\text { It is low carbon, resource efficient, and socially inclusive." }\end{array}$ \\
\hline $\begin{array}{l}\text { International } \\
\text { Chamber } \\
\text { of Commerce, } 2012\end{array}$ & $\begin{array}{l}\text { "...an economy in which economic growth and environmental responsibility } \\
\text { work together in a mutually reinforcing fashion, while supporting progress } \\
\text { on social development..." }\end{array}$ \\
\hline Diyar et al., 2014 & $\begin{array}{l}\text { "...the economy where the growth of the people's welfare and employment } \\
\text { increase are provided owing to the state and social investments ensuring } \\
\text { reduction of emissions and environmental pollution and stimulating } \\
\text { effective use of energy and resources as well as preventing from any harm } \\
\text { to biodiversity and ecosystem" }\end{array}$ \\
\hline
\end{tabular}

Source: own elaboration

Green economy is characterised by a considerable increase in investment in sectors of economy creating and reinforcing the natural capital of the Earth or contributing to decreasing ecological deficiencies and environmental threats. These sectors include, in particular, renewable energy, low-emission transport, energy-efficient building, clean technologies, waste management improvement, sustainable agriculture and forest management and sustainable fishing (Hamdouch and Depret 2010; UNEP, 2010a).

During the Rio +20 Conference potential directions for implementation of the concept of green economy were identified with the emphasis on the necessity of continuing promotion of sustainable development through focussing on key problems, i.e. elimination of poverty, ensuring intra- and intergenerational justice, improvement of economic effectiveness and more equitable access to resources (Caprotti and Bailey, 2014).

Without any doubt, the main reason behind the emergence and development of the concept of green economy and green growth is the movement towards a more integrated and comprehensive approach to incorporating the environment in economic processes. Both concepts aim to identify possible ways of improving the results of economic activity having in mind the existing climatic problems and increasing deficiency in natural resources, mainly through resource- and energy-efficient technological innovations. 
The fact that both concepts aim at a slightly different direction may be somewhat confusing. The concept of green economy aims at economic transformation to foster improvement of social welfare and justice, at the same time considerably reducing environmental threats and ecological deficiencies. Such transformation is to be achieved primarily through "green" investments, creating "green" jobs, creating a market for new products (e.g. ecosystems service market) supporting international trade and the so-called circular economy. A clear-cut goal of green economy is also combating poverty and providing support to developing countries.

To compare, the main objective of the Green Growth Strategy is continuing economic growth, and simultaneously recognising the role of natural capital in planning processes and national accounts. The main measures to achieve this goal include adequate valuation of natural capital considering its role as a production factor (that is, in the first place, ensuring proper measurement of pollution and utilisation of resources, but also preventing risks resulting from limited resources and eliminating harmful subsidies), as well as continuing pressure on innovation and supporting competition (Endl and Sedlacko, 2012).

In turn, the concepts of green growth and green economy are linked by the fact that they are promoted as a remedy to financial and economic crisis. Their purpose is to foster the revival of an impaired global economy by aiming at investments in the market of environmental products and services and the development of "natural" infrastructure, that is, forests, water bodies or biological diversity (Lane, 2010).

According to Allen and Clouth (2012), although green economy and green growth are terms of different origin, that is, they are the result of works of different organisations and different target groups, differences between these concepts have become unclear and they are now used almost interchangeably. However, it is difficult to unambiguously agree with such an approach.

\section{Green growth and sustainable development}

In the first place, sustainable development is a concept which burst into scientific considerations of a wide spectrum of disciplines in the late 1980s as a result of the publication of the report "Our Common Future" in 1987. The report summarized the achievements and failures of humanity in the $20^{\text {th }}$ century identifying sustainable development as a possible way of improving the existing situation. According to the common and frequently quoted definition of sustainable development, this is development "that meets the needs of the present without compromising the ability of future generations to meet their own needs" (WCED (UN), 1987). The concept gained decidedly more interest after the Rio de Janeiro Earth Summit (1992), which adopted a model programme for implementing sustainable development "Agenda 21". Immediately after the Earth Summit the principle of sustainable development was commonly adopted by governments and in many countries it had a significant impact on priority treatment of environmental goals (Satbyul et al., 2014; UNESCAP, 2005).

From the time of the first definition of sustainable development proposed by the Brundtland Commission, a number of attempts at an alternative definition of this concept have been undertaken (Table 3). Some observers have started claiming that sustainable development is an oxymoron since the term itself is contradictory and mutually exclusive. In addition, it is postulated that if someone can redefine and use the term of sustainable 
development for their own purposes, it becomes insignificant in practice or, what is worse, can be used to camouflage activities that are from a wider perspective destructive to the society of the environment or to pretend "going green" (Kates et. al., 2005).

Table 3 | Selected Definitions of Sustainable Development

\begin{tabular}{|c|c|}
\hline Source & Definition \\
\hline (WCED (UN) (1987) & $\begin{array}{l}\text { "...development that meets the needs of the present without } \\
\text { compromising the ability of future generations to meet their } \\
\text { own needs" }\end{array}$ \\
\hline $\begin{array}{l}\text { Environment Protection Act } \\
\text { (Journal of Laws 2001.62.627, } \\
\text { Art. } 3 \text { par. 50) } \\
\text { (Ustawa z dnia } 27 \text { kwietnia } 2001 \\
\text { r. Prawo ochrony środowiska (... } \\
\text { English...) (Dz.U.2001.62.627) }\end{array}$ & $\begin{array}{l}\text { "...social and economic development which includes } \\
\text { integration of political, economic and social activities } \\
\text { in retaining both the natural balance and the sustainability } \\
\text { of basic natural processes - with the aim of balancing } \\
\text { the chances to access the environment by particular } \\
\text { communities or individuals - of both the contemporary and } \\
\text { the future generations" }\end{array}$ \\
\hline Pawłowski, 2006 & $\begin{array}{l}\text { "...programme integrating various aspects (moral, ecological, } \\
\text { technical, economic, legal, social and political) of human } \\
\text { activity based on a moral reflection referring to man's } \\
\text { responsibility for nature" }\end{array}$ \\
\hline Stappen, R. K., 2008 & $\begin{array}{l}\text { "...development that meets the basic needs of all human } \\
\text { beings and which conserve, protect and restore the health } \\
\text { and integrity of the Earth's ecosystem, without compromising } \\
\text { the ability of future generations to meet their own needs } \\
\text { and without going over the limits of long term capacity } \\
\text { of the earth's ecosystem" }\end{array}$ \\
\hline
\end{tabular}

Source: own elaboration

At the beginning of the new millennium the global trend towards sustainable development slowed down significantly. Practical measures undertaken by the states in this respect were insufficient to prevent global changes in the environment. Sustainable development became just one of many obligations of governments. In this situation, however still informally, a need for a "new way" arose (Satbyul et al., 2014).

The concept of green growth emerged and was promoted in 2005 as a possible way of introducing a new, low-emission model of sustainable development for fast developing Asian countries (UNESCAP, 2005). Institutions promoting green growth emphasize that it is not a substitute for sustainable development but a way to achieve it (OECD, 2011; UNEP, 2011; World Bank, 2012).

The concept of green growth, similarly to sustainable development, aims to demonstrate that environmental protection does not need to be at the expense of decreased welfare. However, contrary to sustainable development, green growth directly copes with the problem of economic growth. Sustainable development neglected issues such as general compatibility between growth and environment protection and reassessment of the primary economic objective, that is, the "development". Green growth not only puts an emphasis on such compatibility but claims that environment protection can actually contribute to improving the growth ratios. 
It is frequently indicated that sustainable development is a very broad concept covering many, often mis-defined objectives. This contributed to challenging the meaning of the term or even gave rise to its more conservative or more radical interpretations by various groups of interest (Jacobs, 1999). On the other hand, green growth seems to be a more focussed concept, which can attract a smaller group of adherents (and can even be criticised by the "green" opponents) but its meaning is quite clear. In this sense, green growth is actually something new. It should be undoubtedly treated as a "child" of sustainable development but in fact it is a response to the inadequacies of sustainable development, particularly focussing both on climatic changes and economic growth that have recently dominated in the public debate (Jacobs, 2012).

According to Zervas (2012), a number of differences can be identified between the concept of green growth and sustainable development. Firstly, sustainable development covers a wider bundle of goals. Green growth "loses" the social component, focussing on environmental and economic issues only. Secondly, green growth, as the name suggests, focuses on the category of growth and not on the growth itself which is a broader term. Green growth is only economic growth based on the utilisation of the environment and can have a serious impact on the environment. Moreover, green growth is one of the solutions proposed in the face of the recent economic crisis and thus it is accompanied by other economic or social measures.

The author agrees with the opinion of S. Konstanczak that complete challenging of the validity of the concept of sustainable development has no sense. Sustainable development is a rational direction for the development of our civilisation. The consequence of such thinking is the idea of a new world order which postulates that civilisation should not be eliminated but its development should be modified towards the so-called "green" culture (Konstanczak, 2014). In November 2010 at the G20 Summit in Seoul green growth was recognized as an integral part of sustainable development (Barbier, 2011).

\section{GG-GE-SD model}

Although both green growth and green economy can be perceived as signs or subcategories of sustainable development or even its direct consequences, in many cases it is clearly indicated that these terms must be differentiated.

In the author's opinion parallel functioning of three "green" ideas is not contradictory. On the contrary, complementary and synergistic relationships can be identified between them. The starting point for analysing links between these three concepts is the position that sustainability, and thus sustainable development, is the goal we should ultimately aim at.

The primary assumption of the idea of green economy or green growth is not replacing the concept of sustainable development, but the conviction that achieving sustainable development should be based on an adequately oriented economy is certainly growing. The building of green economy based on the assumptions of the strategy of green growth must become an integral element of economic policy on the way towards sustainable development.

Mutual relations between the concept of green economy, green growth and sustainable development must be looked at from the point of view of mutual feedbacks. Previous approaches to a large extent focussed on competitive relationships, excluding mutual functioning of the analysed concepts. In this part I would like to propose a complementary and synergistic approach. This will be achieved by the proposed model of relationships: GG (green growth) - GE (green economy) - SD (sustainable development) (Figure 1). 


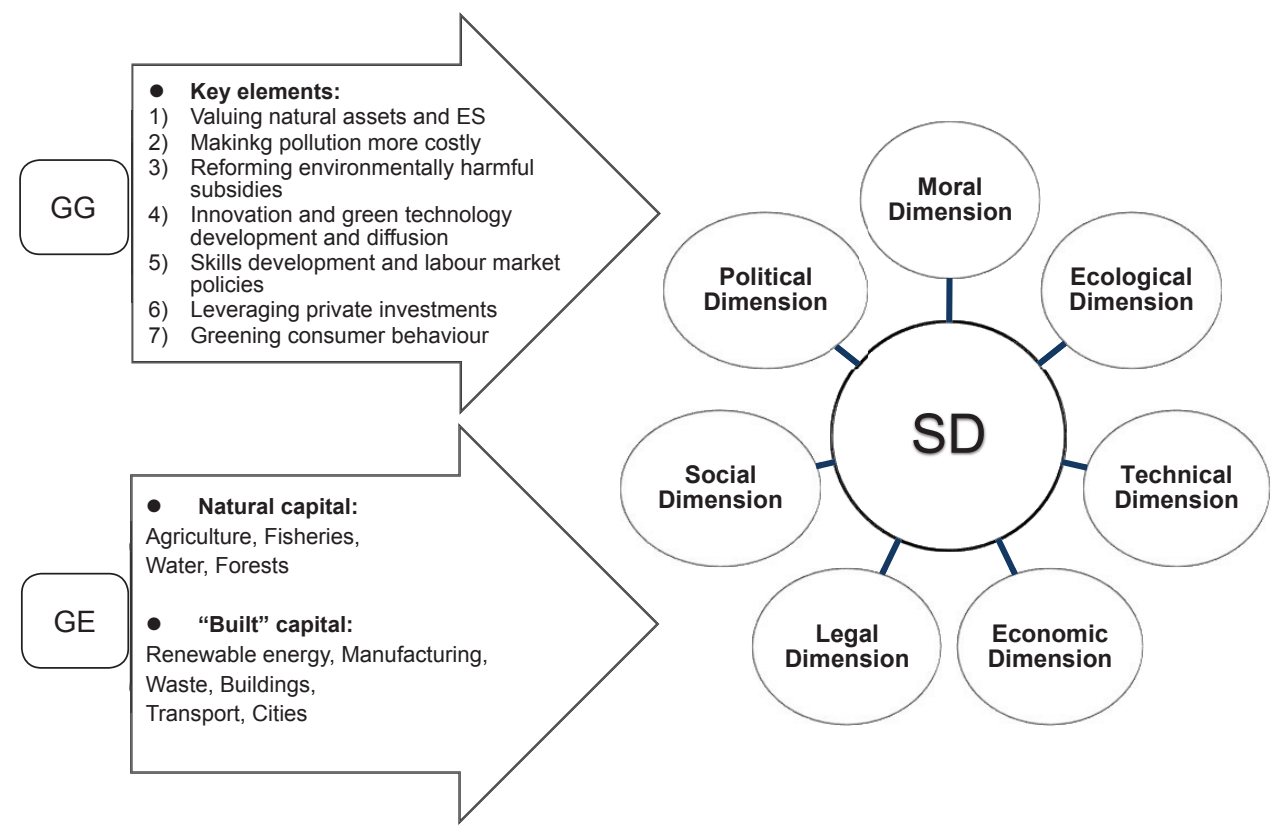

Source: own elaboration based on (Pawłowski 2006; UNEP 2011; OECD 2012)

Sustainable development has steadfastly remained the final, main purpose of activities undertaken according to this model. So far another equally good solution regarding the development of the present and the future generations has not been indicated; therefore we should not focus on "why we cannot succeed" but rather on "what we can do to succeed". The author believes that possible solutions in that respect are offered by the assumptions of green growth and green economy.

The proposed model of achieving sustainable development (Figure 1), as the starting point indicates a properly designed green growth strategy (GG). Once again it should be emphasized that green growth is not to replace sustainable development. On the contrary, it should constitute a practical and flexible approach to achieving specific, measurable progress in two key aspects: economic and environmental, fully recognizing the social consequences of greening the growth of respective economies. Green growth can provide a solution to economic and ecological problems and create new sources of growth through:

- $\quad$ Stimulating an increase in the effective use of resources and natural assets: increasing effectiveness, reducing the amount of waste and energy consumption and ensuring the most effective utilisation of available resources.

- Introducing innovations which could be stimulated by policies and general terms and conditions providing ways to use new solutions to ecological problems.

- Creating new markets thanks to stimulating the demand for green technologies, goods and services; creating new employment opportunities.

- Enhancing the trust of investors by increasing the predictability and stability of the government's activities concerning major issues related to environmental protection. 
- More sustainable macroeconomic conditions, smaller variability in the prices of resources and supporting budget consolidation, for example, by reviewing the structure and effectiveness of public expenditure as well as increasing income thanks to assessment of the effects of pollution (OECD, 2012).

Green growth strategies should in particular focus on numerous social problems including equity, which can follow directly from the implemented solutions both at the national and international level. Effective strategies should cover seven key elements incorporated in the model (Figure 1) which will condition the achievement of sustainable development.

The second element is green economy (GE). Here, the key is the identification of all areas to "go green". On the one hand, green economy covers sectors deriving from the natural capital, e.g. agriculture, fishing, forest and water management. These sectors have a significant influence on the economy since they provide the basis for production but also due to the fact that the living conditions of the rural population are directly determined by such resources. On the other hand, green economy also refers to sectors based on the so-called. "human-made capital", conventionally referred to as "brown" sectors of the economy. Sectors such as transport, energy and production have a large potential for saving energy and resources. Such savings can also fuel economic growth and an increase in employment. Effective utilisation of resources is a multi-dimensional issue since it can refer to energy and material effectiveness and improved waste management.

The ten sectors presented on Figure 1 must be regarded as key sectors in the process of economic transformation. The "greening" of the economy can generate consistent and positive effects such as increased wealth, increased economic production, decent work and reduced poverty (UNEP, 2011).

In the economic dimension, green economy and green growth are to enable the overall increase in welfare; in the social aspect they will translate into improvement in life quality, while in the environmental dimension they will contribute to reducing pressure on the environment and improving the effectiveness of how natural capital is utilised. A properly designed green growth strategy, in combination with comprehensive "greening" of the economy, will help it permanently enter the path to sustainable development.

\section{Conclusions}

In the case of the global crisis, the EU's activities towards sustainable development have undergone a serious slowdown. The discussion has been much distanced from the original starting point, i.e. satisfying the needs within clearly specified limits determined by the environment. The growing understanding for biophysical limits which should not be exceeded in connection with the global economic and financial crisis reoriented the entire discussion concerning the above-mentioned problem back to economic growth within the existing limits (Volkery and Rouabhi, 2015).

Activities for green economy and green growth open doors for a more extensive debate, thus creating a chance to reactivate the universal objective, that is, sustainable development. By reorienting the economy to ensure a mutual synergy of economic growth and environmental protection, green growth strategies aim to support the conventional paths of economic development in a better adaptation to implementing the objectives of sustainable development. Such strategies can help build green economy characterised by a significant increase in investment in the areas of economic activity based on and 
increasing the Earth's natural capital, at the same time reducing ecological and environmental deficiencies.

The key advantage of the emergence of the concepts of green growth and green economy is the fact that they stimulated international attention and renewed global efforts for transforming our present non-sustainable economic model in the direction consistent with the imperative objectives of sustainable development. Importantly, the efforts of international organisations, main groups of interest, teams of experts and representatives of science (both adherents and critics) have led to developing the operating principles both for green growth and green economy, and made it possible to develop a set of tools and measures for national policies. "Green" concepts have revived the global debate on a new definition of our economic model to achieve the agreed imperative objective, that is, sustainable development.

Thus, taking into account the goal we should be aiming at, the following definition of green growth can be proposed: economic growth which contributes to rational utilisation of natural capital, prevents and reduces pollution, and creates chances to improve the overall social welfare by building green economy, and finally makes it possible to enter on the path towards sustainable development. Such a treatment makes it possible to emphasize the integrity of the trio: green growth-green economysustainable development.

\section{References}

Allen, C., Clouth, S. (2012). A Guidebook to the Green Economy. Issue 1: Green Economy, Green Growth, and Low-Carbon Development - History, Definitions and a Guide to Recent Publications. UN Division for Sustainable Development.

Barbier, E. B. (2009). Rethinking the Economic Recovery: A Global Green New Deal. Report prepared for the Economics and Trade Branch, Division of Technology, Industry and Economics, UNEP.

Barbier, E. B. (2011). The Policy Challenges for Green Economy and Sustainable Economic Development. Natural Resources Forum, 35(3), 233-245. https://doi. org/10.1111/j.1477-8947.2011.01397.x.

Caprotti, F., Bailey, I. (2014). Making Sense of the Green Economy. Geografiska Annaler: Series B, Human Geography, 96(3), 195-200. https://doi.org/10.1111/geob.12045

Diyar, S., Akparova, A., Toktabayev, A., Tyutunnikova, M. (2014). Green Economy - InnovationBased Development of Kazakhstan. Procedia - Social and Behavioral Sciences, 140, 695-699. https://doi.org/10.1016/j.sbspro.2014.04.497.

Endl, A., Sedlacko, M. (2012). National Sustainable Development Strategies - What Future Role with Respect to Green Economy? UNCSD Side Event Policy Brief, European Sustainable Development Network (ESDN), Vienna.

Global Green Growth Institute (GGGI) (2012). Green Growth Planning GGGI Country Programs. [Retrieved 2015-10-05] Available at: http://www.gggi.org/project/main

Green Economy Coalition (2010). Green, Fair and Productive: How the 2012 Rio Conference Can Move the World Towards Sustainability. [Retrieved 2015-11-03] Available at: http://www. greeneconomycoalition.org/sites/default/files/documents/ GEC_Rio2012_0510.pdf

Green Growth Leaders (2011). Shaping the Green Growth Economy. A Review of the Public Debate and the Prospects for Green Growth. Copenhagen. 
Hamdouch, A., Depret, M. H. (2010). Policy Integration Strategy of the 'Green Economy': Foundations and Implementation Patterns. Journal of Environmental Planning and Management, 53(4), 473-490.

International Chamber of Commerce (2011). Ten Conditions for a Transition Towards a "Green Economy". Document No. 213-18/7, prepared by the ICC Commission on Environment and Energy. [Retrieved 2015-11-03] Available at: http://uscib.org/docs/10\%20Conditions\%20 Green\%20Economy_FINAL.pdf

International Chamber of Commerce (2012). Green Economy Roadmap. A Guide for Business, Policymakers and Society. Document No 213-18/8.

Jacobs, M. (1999). Sustainable Development as a Contested Concept, in Dobson, A., ed., Fairness and Futurity: Essays on Environmental Sustainability and Social Justice. Oxford: University Press, 21-45. https://doi.org/10.1093/0198294891.003.0002.

Jacobs, M. (2012). Green Growth: Economic Theory and Political Discourse. Centre for Climate Change Economics and Policy, Working Paper No. 108. Grantham Research Institute on Climate Change and the Environment, Working Paper No. 92.

Kates, R. W., Parris, T. M., Leiserowitz, A. A. (2005). What Is Sustainable Development? Goals, Indicators, Values, and Practice. Environment: Science and Policy for Sustainable Development, 47(3), 8-21. https://doi.org/10.1080/00139157.2005.10524444.

Kijek, T., Kasztelan, A. (2013). Eco-Innovation as a Factor of Sustainable Development. Problemy Ekorozwoju/Problems of Sustainable Development, 8(2), 103-112.

Konstańczak, S. (2014). Theory of Sustainable Development and Social Practice. Problemy Ekorozwoju/Problems of Sustainable Development, 9(1), 37-46.

Lane, R. (2010). The Crisis from the Point of View of Evolutionary Economics. International Journal of Social Economics, 37(6), 466-471. https://doi.org/10.1108/03068291011042337.

OECD (2009). OECD and Green Growth. Paris: Organization for Economic Cooperation and Development.

OECD (2011a). Green Growth Strategy, Paris: Organization for Economic Cooperation and Development.

OECD (2011b). Towards Green Growth, Paris: Organization for Economic Cooperation and Development.

OECD (2011c). Towards Green Growth: Monitoring Progress. OECD Indicators. Paris: Organization for Economic Cooperation and Development.

OECD (2011d). Towards Green Growth (Summary in Polish) / Dążenie do rozwoju ekologicznego (Streszczenie w języku polskim). Paris: Organization for Economic Cooperation and Development.

OECD (2012). Inclusive Green Growth: For the Future We Want, Paris: Organization for Economic Cooperation and Development.

OECD (2014). Green Growth Indicators 2014 (Summary in Polish) / Wskaźniki ekologicznego wzrostu gospodarczego - 2014. Paris: Organization for Economic Cooperation and Development. https://doi.org/10.1787/e-4256162666663905574-pl.

Pawłowski, A. (2006). Wielowymiarowość Rozwoju Zrównoważonego. Problemy Ekorozwoju/ Problems of Sustainable Development, 1 (1), 23-32.

Reilly, J. M. (2012). Green Growth and the Efficient Use of Natural Resources. Energy Economics, 34, 585-593. https://doi.org/10.1016/j.eneco.2012.08.033. 
Republic of Korea (2009). Road to Our Future: Green Growth: National

Strategy and the Five-Year Plan (2009-2013). [Retrieved 2015-11-03]

Available at: http://english.mest.go.kr/web/42208/en/board/enview.

do?bbsld=265\&pageSize $=10 \&$ currentPage $=13 \&$ boardSeq $=1226 \&$ mode $=$ view

Republic of Korea (2010). Framework Act on Low Carbon, Green Growth. Act No. 9931, Jan. 13, 2010, Seoul: Ministry of Government Legislation

Republic of Rwanda (2011). Green Growth and Climate Resilience. [Retrieved 2015-11-03] Available at: http://www.smithschool.ox.ac.uk/wp-content/uploads/2011/03/RwandaGreen-Growth-Strategy-FINAL.pdf

Satbyul, K. E., Ho, K., Yeora, C. (2014). A New Approach to Measuring Green Growth: Application to the OECD and Korea. Futures, 63, 37-48. https://doi.org/10.1016/j. futures.2014.08.002.

Stappen, R. K. (2008). A Sustainable World is Possible. Problemlösungen für das 21. Jahrhundert mit dem Wise-Consensus Verfahren. [Retrieved 2015-11-03] Available at: http://www.faape. org/wise-consensus-4-2008.pdf

UNEP (2010a). Green Economy: Driving a Green Economy Through Public Finance and Fiscal Policy Reform, Working Paper v. 1.0. [Retrieved 2015-11-03] Available at: http://www.unep.org/ greeneconomy/Portals/88/documents/ger/GER_Working_Paper_Public_Finance.pdf

UNEP (2010b). Green Economy Initiative: Linkages to Sustainable Consumption and Production, Paris, 18-19 March 2010. [Retrieved 2015-11-03] Available at: http://www.unep.fr/scp/ Marrakech/pdf/SCPGE\%20Workshop\%20presentation\%20Steven\%20Stone.pdf

UNEP (2011). Towards a Green Economy: Pathways to Sustainable Development and Poverty Eradication. [Retrieved 2015-11-03] Available at: http://www.unep.org/greeneconomy/ Portals/88/documents/ger/ger_final_dec_2011/Green\%20EconomyReport_Final_ Dec2011.pdf

UNESCAP (2005). State of Environment Asia and the Pacific 2005. Bangkok.

UNESCAP (2012). Green Growth, Resources and Resilience. Environmental Sustainability in Asia and the Pacific. Bangkok. ISBN 978-92-1-120635-7

Ustawa z dnia 27 kwietnia 2001 r. Prawo ochrony środowiska (Dz.U.2001.62.627). Environment Protection Act (Journal of Laws 2001.62.627)

Volkery, A., Rouabhi, S. (2015). Green Economy and Sustainable Development. A Historical Account of the Discourse around Sustainable Development and Green Economy, KNOSSOS Policy Briefings: Green Economy, Discussion Paper, UNEP, IEEP, GLOBE-EU. [Retrieved 201511-03] Available at: http://www.unep.org/research4policy/ policybriefs/tabid/78428/ Default.aspx

WCED (UN) (1987). Our Common Future. Report of the World Commission on Environment and Development, New York: World Commission on Environment and Development.

World Bank (2012). Inclusive Green Growth: The Pathway to Sustainable Development. Washington D.C.: The World Bank. [Retrieved 2015-11-03] Available at: http://siteresources. worldbank.org/EXTSDNET/Resources/Inclusive_Green_Growth_May_2012.pdf

Zervas, E. (2012). Green Growth versus Sustainable Development. Recent Advances in Energy, Environment and Economic Development, ed. Eslamian S., Proceedings of the 3rd International Conference on Development, Energy, Environment, Economics (DEEE '12), Paris, France, December 2-4, 2012, 399-404. 